\title{
耐力劣化する構造物の信頼性評価法
}

\section{RELIABILITY-BASED LIFE ASSESSMENT OF DEGRADING STRUCTURES}

\author{
森 保宏* \\ Yasuhiro MORI
}

\begin{abstract}
Structures may be affected by changes in strength and stiffness due to aging and/or repeated loading beyond the baseline conditions assumed for design. Since these changes may impair the safety and serviceability of a structure, they should be considered as part of a design process and the process by which a structure is evaluated for continued future service. This paper describes methods using structural reliability principles to evaluate time-dependent reliability of structures subjected to an aggressive environment and/or repeated loading. These methods enable the impact on safety and serviceability of uncertainties in loading conditions, structural strength, and strength degradation to be assessed quantitatively. The effect of periodic inspection and maintenance on time-dependent reliability also is considered.
\end{abstract}

Keywords : reliability, degradation, aging, repeated load, resistance, maintenamce 信頼性, 劣化, 経年変化, 繰返し荷重, 抵抗, メンテナンス

\section{1 はじめに}

現在の構造信頼性理論の展開の中では多くの場合，特 に設計法の展開の中では構造耐力は時間領域で変化しな い(時間に対して独立な) 確率变数として取り扱われ, 荷重効果の時間的変化のみが考虑されている。しかしな がら，実際には構造物の耐力および剛性は，使用期間中 に荷重効果による損傷や経年変化により，構造設計の際 に用いられた基準状態から変化する場合がある。このよ うな変化の中には 10 年あるいはそれ以上継続するコン クリー-トの水和反応 ${ }^{1)}$ のように有益なものもあるが, 多 くは，特に構造物が大きな荷重効果を繰り返し受ける場

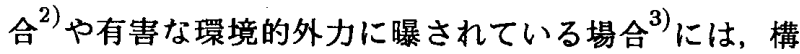
造体あるいは構造部材の耐力は長い間に劣化し，構造物 が限界状態に入り込む危険性は增大する。例えば，二酸 化炭素の濃度の高い工業地帯では鉄筋を保護しているコ ンクリートの中性化速度は速く，鉄筋の腐食を早期に誘 発し、コンクリートのひびわれ，鉄筋の断面欠損へと至 る。また, 過大な荷重効果を受けたとき, 構造部材は塑
性変形等により損傷を受け，構造物の耐力は低下する。 構造物の総費用最小化の概念に基つくく最適設計 ${ }^{4) 5}$ を行 う場合, あるいは現存する社会施設の保全を限られた資 源を用いて効率良くすすぬる場合には，このような構造 耐力の時間的変化, さらにはメンテナンスの効果を考慮 に入れた信頼性の評価が必要である。

Mori \& Ellingwood ${ }^{677}$ は構造耐力が環境要因によって 劣化する場合の構造部材および構造システムの信頼性 評価手法を提示し, 耐力劣化する構造物の信頼性は, 劣 化の時間的変化を表す関数の形, 劣化のレベル, および 荷重効果の確率モテルに対し敏感であり，また，この手 法が最適な点検・メンテナンス計画の決定に適用可能で あることを示した。洪・高梨 ${ }^{8)}$ は経年劣化を考庶に入れ た構造部材の信頼性評価手法を最適設計法に適用し，荷 重係数が劣化の度合いと共にほぼ直線的に大きくなるこ とを示した。これらの研究では耐力劣化は荷重履歴に対 して独立であり，時間のみに依存した関数と考えられて いる。

\footnotetext{
“名古屋大学工学部地圏環境工学専攻 助手. Ph.D Assist. Prof., Dept. of Geotechnical and Environmental
} Engineering, School of Engineering, Nagoya Univ., Ph. D. 
荷重履歴による劣化は荷重効果と構造物の耐力との相 互依存によるので非常に複雑になる。Kameda \& Koike ${ }^{2)}$ は荷重劣化効果をランダムな大きさの荷重効果の関数と して表し, 荷重生起後の耐力の確率密度関数を随時更新 していくことにより劣化する構造物の信頼性を評価し た。しかしながら, 結果として得られる評価式には荷重 効果のランダム性を考虑したことによる多重積分が含ま れ，荷重の生起回数が多い場合への適用は実際的ではな い。洪・高梨9) $($ 荷重効果の大きさの変動が大きな場合 でも, 荷重効果による劣化の変動が小さければ, この荷 重劣化効果は荷重効果の大きさの平均值を用いて近似的 に評価できるとして, 荷重生起回数の多い場合にも適用 できる信頼性評価法を提示した。これらの研究では耐力 劣化は荷重の生起回数のみの関数として表されている。

以上のように, 環境要因により劣化する場合と荷重履 歴により劣化する場合の構造物の信頼性解析は個別に展 開され, 劣化関数の取扱いの違いから, それぞれの解析 手法は他方の要因により劣化する場合への適用は考慮さ れていない。しかしながら，実際には構造物は環境要因 と荷重履歴のどちらか一方ではなく両方の影響を受けて 劣化すると考えるのが自然である。

本論は, 環境要因および荷重履歴による構造耐力の劣 化を時間に依存する信頼性解析の中に組み込み, 荷重効 果の大きさ, 生起回数ならびに生起時刻, および部材の 初期耐力における不確定性を考慮に入れた，構造物の信 頼性評価法に関するものである。荷重履歴による耐力劣 化を環境要因による耐力劣化と同様に時間の関数とし て近似評価することにより両者の劣化効果による耐力 劣化を考慮に入れた構造信頼性の評価が可能となり, ま た，それぞれの劣化要因の構造信頼性に対する影響を同 じ時間軸で比較することができる。環境要因により鉄筋 コンクリート構造物の耐力劣化関数は定性的に評価する ことができる゙）ここでは, 荷重履歴による耐力劣化を Kameda \& Koike ${ }^{10)}$ の劣化モデルにより評価し，様々な パラメータが構造物の劣化関数および時間に依存する信 頼性にどのような影響を与えるかを簡単な構造部材モデ ルを用いた解析例により示す。また，モンテカルロ法に よる評価結果との比較により荷重劣化効果を時間の関数 として近似評価をすることの妥当性について検討を加え ている。

\section{2 荷重の確率モデル}

構造物の信頼性評価をする上で，適切な荷重の確率モ デルの設定は重要な問題である。構造物に大きな影響を 及ぼす荷重は, 時間的にランダムに発生し，またその大 きさもランダムである。構造物の寿命と考えられる 40 年あるいはそれ以上の時間のスケールでみると荷重の継

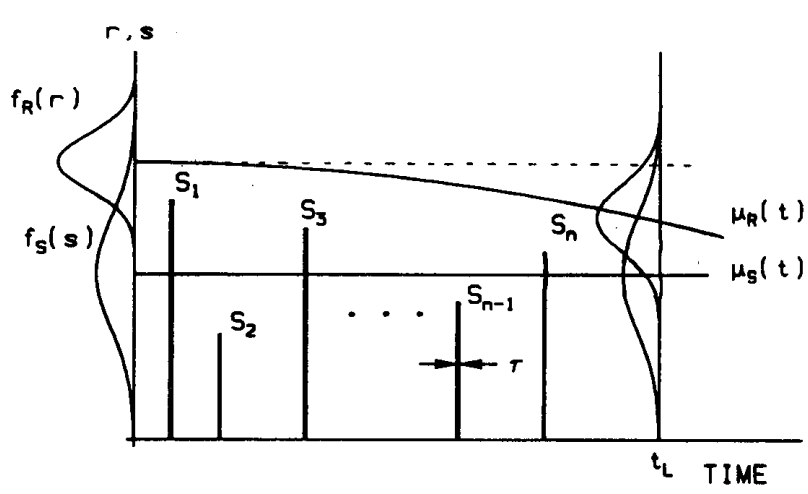

図 1: 荷重と抵抗の劣化の概略図

続時間は一般に非常に短くこのような事象は使用期間 中のごくわずかな時間を占めるにすぎない。このような 仮定から，大きさが時間的に不規則に変化する荷重は図 1 に示されるような, ランダムな大きさ $S_{j}$ ，およびラン ダムな継続時間 $\tau_{j}$ をもった, ランダムに生起するパル スの時系列としてモデル化することができよう。ここで は, 荷重の継続時間は十分に短く, 荷重が作用している 最中の耐力劣化はないものと仮定する。以上の考察より 荷重の生起は, 平均生起率入をもつポアソン・インパル ス過程としてモデル化することができ，このとき，時間 $(0, t]$ 間に $N(t)=n$ 回の事象が発生する確率は下式で表 される。

$$
P[N(t)=n]=\frac{(\lambda t)^{n} \cdot e^{-\lambda t}}{n !} ; n=0,1,2, \ldots
$$

ここに, $P[\bullet]$ は, 事象・が発生する確率を表す。さらに, 一連の荷重効果の大きさ $S_{j}(j=1,2, \ldots)$ を独立同分布 で確率分布関数 $F_{S}(s)$, 確率密度関数 $f_{S}(s)$ を持つ確率 変数と仮定することにより, 離散的不規則過程としての 荷重モデルを構成することができる。

\section{3 耐力変化を無視した場合の信頼性解析}

単一荷重を受ける構造物の信頼性 $L$ は下式で表すこ とができる ${ }^{11) 12) 。 ~}$

$$
L=P[R>S]=\int_{0}^{\infty} F_{S}(r) f_{R}(r) d r
$$

ここで, $f_{R}(r)$ は荷重効果 $S$ と同じ単位を持つ構造抵抗 $R$ の確率密度関数である。

時間 $\left(0, t_{L}\right]$ に一連の荷重を受けるとき耐力変化がない と仮定した場合は構造物は構造抵抗が時間 $\left(0, t_{L}\right]$ に生起 する荷重効果の最大値より大きければ限界状態に入り这 まない。従って, この時の信頼性は下式で表すことがで きる。

$$
L\left(t_{L}\right)=P\left[R>S_{\max }\left(t_{L}\right)\right]
$$




$$
=\int_{0}^{\infty} F_{S_{m a x}}\left(r ; t_{L}\right) f_{R}(r) d r
$$

ここに, $F_{S \max }\left(s ; t_{L}\right)$ は時間 $\left(0, t_{L}\right]$ 間に生起する最大 荷重効果 $S_{\max }\left(t_{L}\right)$ の累積分布関数であり, 荷重の生起 が平均発生率 $\lambda$ のポアソン過程にしたが, かつ, 時刻 $t=0$ において荷重が作用していない場合は全確率の定 理を用いて下式より得ることができる。

$$
\begin{aligned}
& F_{S_{\max }\left(t_{L}\right)}\left(s ; t_{L}\right) \\
& \quad=\sum_{n=0}^{\infty} P\left[S_{\max }<s \mid N\left(t_{L}\right)=n\right] \cdot P\left[N\left(t_{L}\right)=n\right] \\
& \quad=\sum_{n=0}^{\infty}\left\{F_{S}(s)\right\}^{n} \cdot \frac{\left(\lambda t_{L}\right)^{n} \cdot e^{-\lambda t_{L}}}{n !} \\
& \quad=\exp \left[-\lambda t_{L}\left\{1-F_{S}(s)\right\}\right]
\end{aligned}
$$

時刻 $t$ において構造物が限界状態に入り込んでいないと いう条件の下で，引き続く微小時間 $d t$ に限界状態に入 り込む確率, すなわち危険率 $h(t)$ は, 信頼性関数 $L(t)$ との間に次式の関係がある。

$$
h(t)=-\frac{d}{d t} \ln \{L(t)\}
$$

耐力にばらつきがある構造物がランダムな大きさの一 連の荷重効果を受けるとき, 耐力の小さな構造物は早く 限界状態に入り込むが, 耐力の大きな構造物は限界状態 に入り込まずその信頼度は增加する。これを非破壊効果 と呼ぶ”。既存の構造物の信頼性評価においては, 耐力 に関する新たな情報として過去の荷重履歴による非破壊 効果を考虑し, 耐力の確率密度関数を更新する必要があ る。しかし, 将来における非破壊効果は危険率および信 頼性関数にはその定義から明らかなように含まれている ので, あらためて考懬する必要はない。

\section{4 耐力劣化を考慮した場合の信頼性解析}

\section{1 環境要因のみによる劣化}

耐力劣化を考慮した場合の信頼性解析の基本的な概念 を示すために，図 1 に示すような時系列のランダム荷重 効果を受ける構造部材を考える。部材の抵抗は, 環境要 因により（6) 式で表されるように時間とともに低下す ると仮定する。

$$
R(t)=R_{0} \cdot G_{a}(t)
$$

ここに, $R(t)$ は時刻 $t$ における部材の耐力, $R_{0}$ は劣化 していない初期の状態の部材の耐力, $G_{a}(t)$ は環境要因 による劣化関数であり荷重履歴に独立であると仮定す る。劣化のメカニズムは不確定性をもち，実驗データは 不足しているため, 劣化関数 $G_{a}(t)$ は確率変数として取 り扱わなければならない。しかし, 劣化関数の不確定性
を正しく評価することは非常に困難であるので, ここで は $G_{a}(t)$ は確定的でありその平均 $E\left[G_{a}(t)\right]=g_{a}(t)$ に等 しいとする。

ここで,一時 $R_{0}=r$ とする。時間 $\left(0, t_{L}\right]$ の間に $N\left(t_{L}\right)=n$ 個の荷重が結合確率密度関数 $f_{\mathbf{T}}(\mathbf{t})$ を持つ ランダムな時刻 $\mathbf{T}=\left\{T_{1}, \ldots, T_{n}\right\}\left(T_{1}<T_{2}<\ldots<T_{n}\right)$ に生起したとすると部材の信頼性関数, すなわち, 時間 $\left(0, t_{L}\right]$ の間に部材が限界状態に入り込まない確率は下式 で表される。

$$
\begin{aligned}
L\left(t_{L}\right) & =P\left[r \cdot g_{a}\left(T_{1}\right)>S_{1} \cap \ldots \cap r \cdot g_{a}\left(T_{n}\right)>S_{n}\right] \\
& =\underbrace{\int_{0}^{t_{L}} \cdots \int_{0}^{t_{2}}}_{n \text { 重積分 }}\left[\prod_{j=1}^{n} F_{S}\left\{r \cdot g_{a}\left(t_{j}\right)\right\}\right] f_{\mathbf{T}}(\mathbf{t}) d \mathbf{t}
\end{aligned}
$$

荷重の生起がポアソン過程ならば， $\left(0, t_{L}\right]$ 間に生起する 回数が $n$ 回であるという条件の下では, ランダムな生起 時刻 T は独立同分布で， $\left(0, t_{L}\right]$ 間で一様に分布してい る確率変数 $\mathbf{T}^{*}=\left\{T_{1}^{*}, \ldots, T_{n}^{*}\right\}$ の順序統計量である ${ }^{13)}$ 。 $\mathrm{T}^{*}$ の結合確率密度関数は,

$$
f_{\mathbf{T}^{*}}\left(\mathbf{t}^{*}\right)=\frac{1}{\left\{t_{L}\right\}^{n}}
$$

であり，荷重効果の大きさは独立同分布であるから，信 頼性関数は下式となる。

$$
\begin{aligned}
L\left(t_{L}\right) & =\underbrace{\int_{0}^{t_{L}} \cdots \int_{0}^{t_{L}}}_{n \text { 重積分 }}\left[\prod_{k=1}^{n} F_{S}\left\{r \cdot g_{a}\left(t_{k}^{*}\right)\right\}\right] f_{\mathrm{T}^{*}\left(\mathbf{t}^{*}\right) d \mathbf{t}^{*}} \\
& =\left[\int_{0}^{t_{L}} F_{S}\left\{r \cdot g_{a}(t)\right\} \frac{1}{t_{L}} d t\right]^{n}
\end{aligned}
$$

次に $\left(0, t_{L}\right]$ 間に生起する荷重の回数の不確定性を考慮す ると

$$
\begin{aligned}
L\left(t_{L}\right) & =\sum_{n=0}^{\infty}\left[\int_{0}^{t_{L}} F_{S}\left\{r \cdot g_{a}(t)\right\} \frac{1}{t_{L}} d t\right]^{n} \frac{\left(\lambda t_{L}\right)^{n} \cdot e^{-\lambda t_{L}}}{n !} \\
& =\exp \left[-\lambda t_{L} \cdot\left[1-\frac{1}{t_{L}} \int_{0}^{t_{L}} F_{S}\left\{r \cdot g_{a}(t)\right\} d t\right]\right]
\end{aligned}
$$

最後に初期耐力における不確定性を考慮に入れると, 環 境要因により劣化する構造部材の信頼性関数は下式と なる。

$$
\left.L\left(t_{L}\right)=\int_{0}^{\infty} L\left(t_{L}\right\} R_{0}=r\right) f_{R_{0}}(r) d r
$$

ここで $f_{R_{0}}(r)$ は荷重効果 $S$ と同じ単位を持つ初期抵抗 $R_{0}$ の確率密度関数, $L\left(t_{L} \mid R_{0}=r\right)$ は (10) で与えられる。 時間 $\left(0 ; t_{L}\right]$ の間に部材が限界状態に入り込む確率（限界 状態確率) は下式で表される。 


$$
F\left(t_{L}\right)=1-L\left(t_{L}\right)
$$

\section{2 繰り返し荷重のみによる劣化}

$i$ 回目の荷重効果 $S_{i}$ を受けているときの耐力劣化は $i-1$ 回目までの荷重効果にのみ影響され， $S_{i}$ を受けて いる最中の耐力劣化はなく，また， $S_{i}$ による耐力劣化は $S_{i}$ を受けた直後に起こるとすると，荷重履歴のみにより 耐力が劣化する場合は, 劣化関数 $G_{\ell}(t)$ は階段状関数と なる。従って，ある時刻における劣化の割合はそれまで に生起した荷重の回数とそれらの荷重効果の大きさに依 存するが, 荷重の生起時刻には依存せず, 荷重履歴のみ により耐力少化する場合の信頼性解析では荷重の生起時 刻のランダム性を考慮する必要はない。

荷重効果 $S_{i}$ による耐力劣化の割合が， $S_{i}$ に依存する 関数 $\phi\left(S_{i}\right)$ によって下式のように表されるものと仮定す $ろ^{2) 9)}$ 。

$$
R_{i}=R_{i-1} \cdot \phi\left(S_{i}\right)
$$

ここに, $R_{i}$ は, $i$ 回目の荷重効果を受けた後の構造物の 残存耐力，また，

$$
\phi\left(S_{i}\right) \leq 1
$$

$i$ 回目の荷重効果を受けた後の $(i+1$ 回目の荷重効果を 受けるときの）残存耐力と初期耐力との間には次式の関 係が成り立つ。

$$
R_{i}=R_{0} \cdot \prod_{j=1}^{i} \phi\left(S_{j}\right)
$$

初期耐力を $R_{0}=r$, 時間 $\left(0, t_{L}\right]$ における荷重の生起回 数を $N\left(t_{L}\right)=n$ とすると信頼性関数は次式のように表 現される。

$$
\begin{aligned}
& L\left(t_{L}\right)= P\left[r>S_{1} \cap r \cdot \phi\left(S_{1}\right)>S_{2} \cap \ldots\right. \\
&\left.\cap r \cdot \prod_{j=1}^{n-1} \phi\left(S_{j}\right)>S_{n}\right] \\
&=\underbrace{\int_{0}^{r} \int_{0}^{r \phi\left(s_{1}\right)} \ldots \int_{0}^{r} \prod_{j=1}^{n-1} \phi\left(s_{j}\right)}_{n \text { 重積分 }} \prod_{i=1}^{n} f_{S}\left(s_{i}\right) d \mathbf{s}
\end{aligned}
$$

（16）式には多重積分が含まれるので荷重の回数が多い場 合まで $L\left(t_{L}\right)$ を精度良く算定することは非常に困難であ る。しかしながら, 荷重履歴による耐力の劣化効果の変 動が小さければ，荷重履歴による劣化は次式により近似 的に評価できる ${ }^{9)}$ 。

$$
\begin{aligned}
R_{i} & \approx R_{0} \cdot \prod_{j=1}^{i} \phi\left(\mu_{S}\right) \\
& =R_{0} \cdot\left\{\phi\left(\mu_{S}\right)\right\}^{i}
\end{aligned}
$$

ここに, $\mu_{S}$ は荷重効果の大きさの平均である。この時, 信頼性関数は次式で表される。

$$
\begin{aligned}
L\left(t_{L}\right) & =P\left[r>S_{1} \cap r \cdot \phi>S_{2} \cap \ldots \cap r \cdot \phi^{n-1}>S_{n}\right] \\
& =\prod_{j=0}^{n-1} F_{S}\left(r \cdot \phi^{j}\right)
\end{aligned}
$$

ここに, $\phi=\phi\left(\mu_{S}\right) 。\left(0, t_{L}\right]$ 間に生起する荷重の回数の 不確定性，および初期耐力における不確定性を考虑に入 れると，信頼性関数は下式となる。

$$
\begin{aligned}
L\left(t_{L}\right)=\int_{0}^{\infty} & e^{-\lambda t_{L}}\left[1+\sum_{n=1}^{\infty} \prod_{j=0}^{n-1} F_{S}\left(r \cdot \phi^{j}\right) \frac{\left(\lambda t_{L}\right)^{n}}{n !}\right] \\
& \times f_{R_{0}}(r) d r
\end{aligned}
$$

\section{3 環境要因および荷重履歴による劣化}

構造耐力が荷重履歴のみにより劣化する場合の信頼性 解析では環境要因により劣化する場合において重要な要 素である荷重の生起時刻のランダム性は考慮されていな いので，両者によって劣化する場合の信頼性評価をする うえで (19) 式を直接用いることはできない。

構造耐力が環境要因と荷重履歴の両者によって劣化す る場合の劣化関数は，時間およびそれまでに発生した荷 重効果の大きさと発生回数の関数として表される。初期 耐力を $R_{0}=r$, 時間 $\left(0, t_{L}\right]$ において $N\left(t_{L}\right)=n$ 回の荷 重が時刻 $\mathbf{T}=\left\{T_{1}, \ldots, T_{n}\right\}\left(T_{1}<T_{2}<\ldots<T_{n}\right)$ に生起 したとする。 $i$ 回目の荷重効果を受けるときの残存耐力 をr.G(T $\left.T_{i}, S_{1}, \ldots, S_{i-1}\right)$ とすると, 信頼性関数は次式と なる。

$$
\begin{aligned}
& L\left(t_{L}\right) \\
& \quad=P\left[r \cdot G\left(T_{1}\right)>S_{1} \cap r \cdot G\left(T_{2}, S_{1}\right)>S_{2} \cap \ldots\right. \\
& \left.\cap r \cdot G\left(T_{n}, S_{1}, \ldots, S_{n-1}\right)>S_{n}\right] \\
& \quad=\underbrace{\int_{0}^{t_{L}} \ldots \int_{0}^{t_{2}} L\left(t_{L} \mid \mathbf{T}=\mathbf{t}\right) f_{\mathbf{T}}(\mathbf{t}) d \mathbf{t}}
\end{aligned}
$$$$
n \text { 重積分 }
$$

ここに,

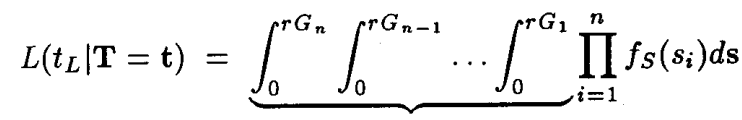$$
n \text { 重積分 }
$$

$$
G_{i}=G\left(t_{i}, s_{1}, \ldots, s_{i-1}\right)
$$

また， $\left\{T_{1}, \ldots, T_{n}\right\}$ は，互いに独立で， $\left(0, t_{L}\right]$ 間で一様 分布している確率変数 $\left\{T_{1}^{*}, \ldots, T_{n}^{*}\right\}$ の順序統計量であ るからその結合密度関数は次式で与えられる。

$$
f_{\mathbf{T}}(\mathbf{t})=\frac{n !}{\left\{t_{L}\right\}^{n}}
$$


(20) 式には $2 n$ 重積分が含まれるので荷重の生起回数が 2 回の場合でさえ $L\left(t_{L}\right)$ を精度良く算定することは困難 である。(17) 式の近似を用いても $n$ 重積分が残る。し かし, 荷重履歴による劣化を近似的に時間のみに依存す る関数として表現できれば環境要因と荷重履歴による劣 化関数 $G(t)$ も時間のみに依存する関数となり, $G(t)$ の 変動係数が小さければ信頼性関数は $(11)$ 式の $g_{a}(t)$ を $g(t)(=E[G(t)])$ に置き換えることにより評価できる。こ こでは，まず，荷重履歴のみにより劣化する場合の信頼 性を(11) 式を用いて評価することを試み，その妥当性を 次節の解析例において検討する。

時間 $(0, t]$ における荷重の生起回数を $N(t)=n$ とす ると時刻 $t$ における劣化関数は下式で与えられる。

$$
G_{\ell}(t)=\prod_{i=1}^{n} \phi\left(S_{i}\right)
$$

劣化関数の平均は，荷重効果の大きさが独立同分布であ ることを考慮すると次式となる。

$$
\begin{aligned}
g_{\ell}(t) & =E\left[G_{\ell}(t)\right] \\
& =\int_{0}^{\infty} \cdots \int_{0}^{\infty} \prod_{i=1}^{n} \phi\left(s_{i}\right) f_{S}\left(s_{i}\right) d \mathbf{s} \\
& =\left[\int_{0}^{\infty} \phi(s) f_{S}(s) d s\right]^{n}
\end{aligned}
$$

$N(t)=n$ の条件を取り除くと

$$
\begin{aligned}
g_{\ell}(t) & =\exp \left[-\lambda t \cdot\left\{1-\int_{0}^{\infty} \phi(s) f_{S}(s) d s\right\}\right] \\
& =\exp [-\lambda t \cdot\{1-E[\phi(S)]\}]
\end{aligned}
$$

劣化効果の変動が小さい場合には $g_{\ell}(t)$ は次式で近似評 価できる。

$$
g_{\ell}(t)=\exp \left[-\lambda t \cdot\left\{1-\phi\left(\mu_{S}\right)\right\}\right]
$$

同様に, $G_{\ell}(t)$ の二次統計量は次式で得られる。

$$
E\left[\left\{G_{\ell}(t)\right\}^{2}\right]=\exp \left[-\lambda t \cdot\left\{1-E\left[\phi(S)^{2}\right]\right\}\right]
$$

環境要因と荷重履歴の両者により劣化する場合の劣 化関数 $G(t)$ は，それぞれの要因のみで劣化する場合の 劣化関数を基に表現することができよう。例えば，一方 が材料強度に，他方が部材断面積に互いに独立に影響を 与える場合には， $G(t)$ は次式のように表すことができ よう。

$$
G(t)=G_{a}(t) \cdot G_{\ell}(t)
$$

それぞれの要因による劣化効果が互いに影響し合う場合 の劣化関数は，その相乗効果をモテル化しなければなら
表 1: 抵抗および荷重モテル

\begin{tabular}{l|c|c|c|c|c}
\hline & $\frac{\mu_{R}}{\mu_{S}}$ & $\frac{\mu_{R}}{\mu_{S_{\max }(60)}}$ & $V_{S}$ & $\begin{array}{c}\lambda \\
\left(\mathrm{yr}^{-1}\right)\end{array}$ & $c_{A}$ \\
\hline Case (A) & 2.65 & 2.49 & 0.20 & 0.1 & 0.1 \\
Case (B) & 5.40 & 1.69 & 0.60 & 0.1 & 0.1 \\
Case (C) & 6.35 & 1.59 & 0.60 & 0.5 & 0.1 \\
\hline
\end{tabular}

$\mu$ 。は・の平均値

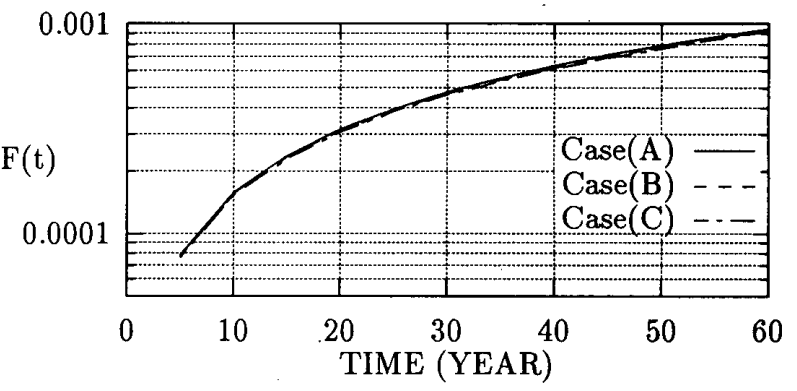

図 2: 劣化を無視した場合の部材の限界状熊確率

ないが、モデル化のためのデータは不十分であり、今後 の研究を待たなければならない。

\section{5 耐力劣化する構造物の信頼性解析の解析例}

部材耐力の劣化が部材の信頼性に及ぼす影響を，表 1 にある簡単な解析モデルを用いて示す。荷重効果の大き さはグンベル分布を有する確率変数, 初期耐力は, 変動 係数 $V_{R}=0.15$ の対数正規確率変数と仮定する。それぞ れの解析では，構造物の供用期間は 60 年と仮定してい る。耐力劣化を考慮しない場合の信頼性は図 2に示すよ うに全ての Case においてほぼ同等である。

\section{1 荷重履歴のみによる劣化}

荷重履歴による劣化モデルとして次式の関数を用いる 9)10)

$$
\phi(s)=\exp \left(-\frac{c_{A} \cdot \mu_{R}}{s}\right)
$$

ここに, $\mu_{R}$ は初期耐力の平均, $c_{A}$ は劣化効果を表す定 数である。

$c_{A}=0.1$ または 0.2 と仮定した場合の劣化効果 $\phi(S)$ の変動係数 $V_{\phi}$ を図 3 に示す。本論文で用いた劣化モ广 ルの $V_{\phi}$ は中央安全率 $\mu_{R} / \mu_{S}$ が小さいほど, 荷重効果の 変動係数 $V_{S}$ が大きいほど增加するが, $c_{A}$ の值に関わら ずその值は小さく，荷重履歴による劣化関数は (27) 式を 用いて近似評価できる。

(26) 式および (28) 式より得られた劣化関数の平均値 $g_{\ell}(t)$ と変動係数 $V_{G_{\ell}}(t)$ を図 4 に示す。同図には $(27)$ 式 


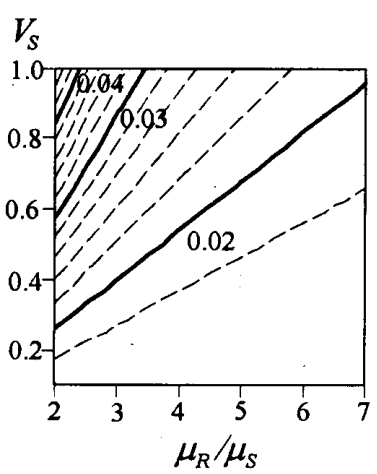

(a) $c_{A}=0.1$

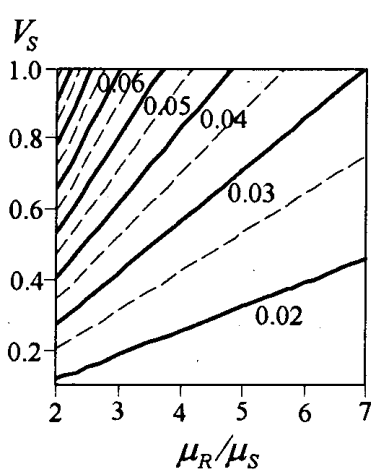

(b) $c_{A}=0.2$
図 3: 劣化効果の変動係数

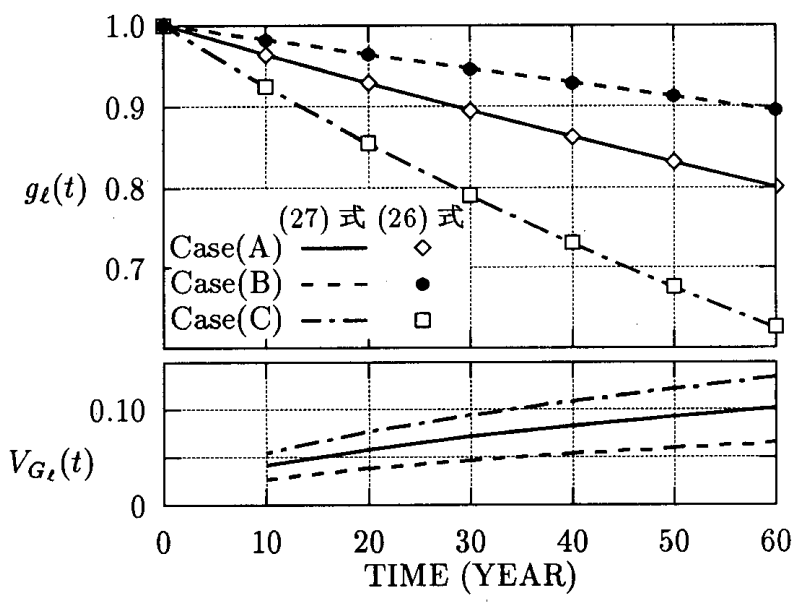

図 4: 劣化関数の平均および変動係数

による劣化関数の平均值も併せて示されている。(27) 式 は劣化関数の良い近似を与えているので以下の解析例で は $g_{\ell}(t)$ の評価に $(27)$ 式を用いる。 $V_{G_{\ell}}(t)$ は時間と共に 增加するが，秢 60 年においてもその值は比較的小さい。

荷重履歴による劣化を考虑にいれた場合の, (19) 式, あるいは，(11）式と（27）式に基つく限界状態確率の評 価結果をモンテカルロ法による解析結果と比較して図 5 に示す。同図には劣化を考虑しない場合の信頼性関数を Case(A) を対象に示してある。モンテカルロ法では時刻 歴で荷重を発生させ劣化効果を (30) 式により順次評価 しながら構造物の残存耐力と荷重効果の大きさを比較し た。サンプル数は $1,000,000$ である。(19) 式（図 5-(a)） は全ての Case について非常に良い近似解を与えている。 これは，(19) 式を得るうえで用いた近似が(17) 式だけで あり，この近似の精度に影響を与える荷重効果による少 化の変動が小さいためと考えられる。一方，(11) 式およ び(27) 式に基づく評価値（図 5-(b)）は，モンテカルロ 法あるいは (19) 式による評価值よりも若干低めの值を示 している。これは $G_{\ell}(t)$ の変動を無視したためと考えら

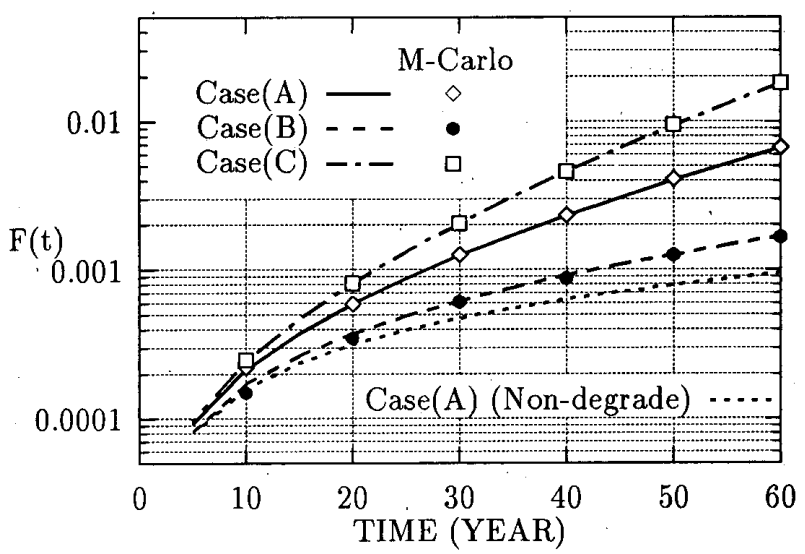

(a) (19) 式による評価

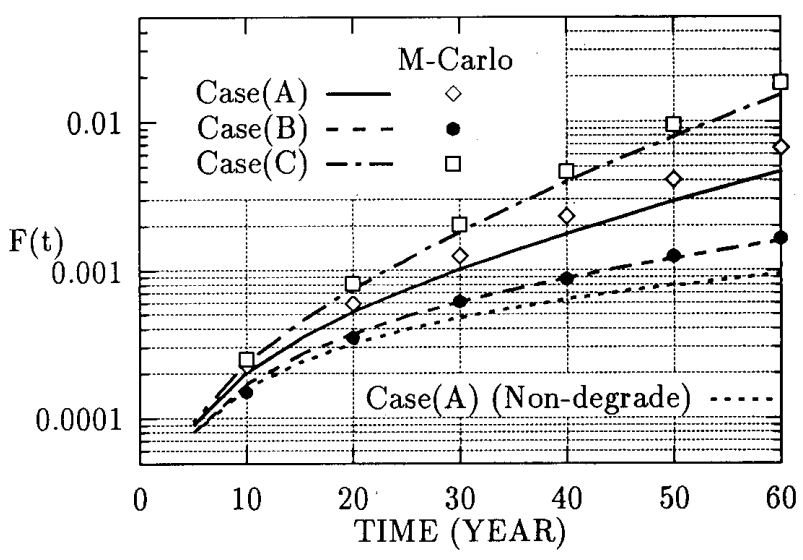

(b) (11) 式および (27) 式による評価

図 5: 荷重履歴により劣化する部材の限界状態確率

れるが，その影響は小さく， $V_{G_{\ell}(60)} \leq 0.15$ ならば，荷 重履歴による劣化を $(27)$ 式により時間の関数として評価 し、構造部材の信頼性を(11) 式により評価する手法は良 い近似解を与えている。また，後で述へるように $V_{G_{\ell}(60)}$ を無視したことによる影響は劣化モデルや荷重・抵抗の 統計量に比へ，限界状態確率に対し 2 次的なものでしか ない。この結果は環境要因により劣化する場合の限界状 態確率と整合している゙

耐力劣化を考虑しない場合の 3 つの解析モデルの信頼 性はほぼ同等であるが，劣化を考慮した場合は，図 4 に 示されるように劣化関数の形状は似ているものの（時間 に対しほぼ直線的）その傾きは大きく異なる。この差異 の限界状態確率に対する影響は大きく, 例えば， $t=60$ 年では Case(A) の限界状態確率は $\operatorname{Case}(\mathrm{C})$ の限界状態 確率の䄪 10 倍となっている。また，それぞれの Caseに おいて $\log \{F(t)\}$ は，齢 15 25 年以降は時間に対し線形 に增加，すなわち， $F(t)$ は指数的に增加している。これ は, 残存耐力が小さいほど限界状態確率は耐力の小さな 変化に敏感であり、この影響が時間を追って蓄䅡される 


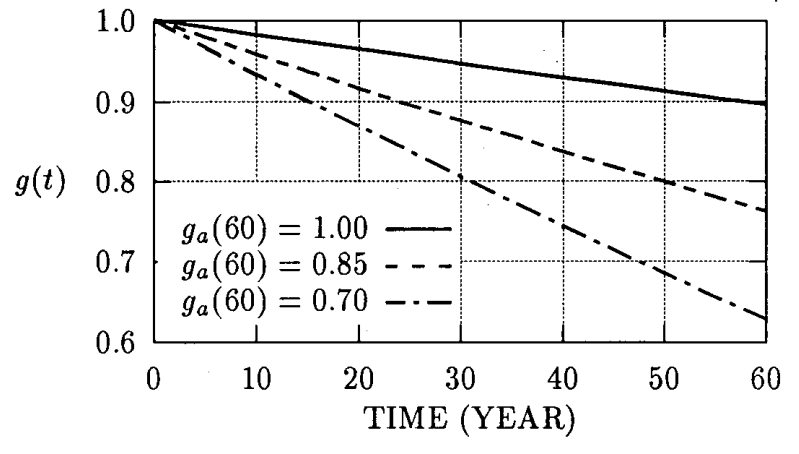

図 6: 環境要因および荷重履歴により劣化する 部材の劣化関数

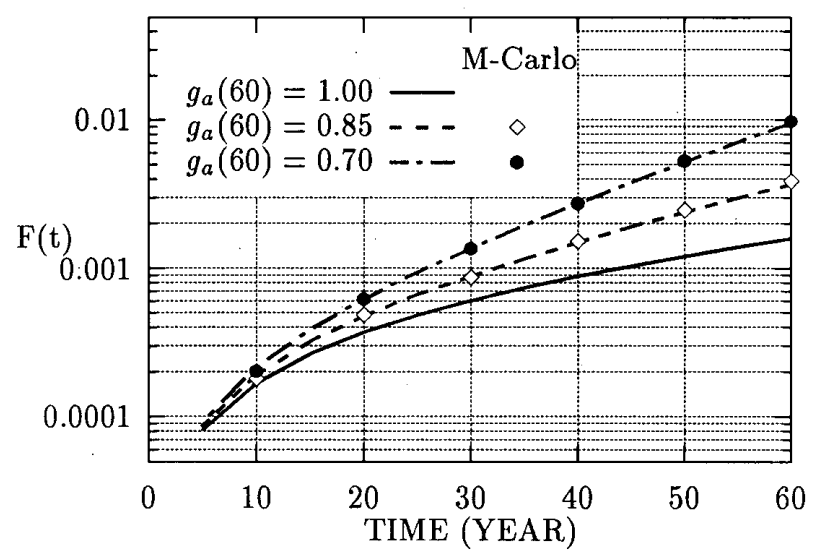

図 7: 環境要因および荷重履歴により劣化する 部材の限界状態確率

からである。図 4および図 5は中央安全率, 荷重の平均生 起率, 荷重効果の大きさの変動係数の適切な評価が荷重 履歴により劣化する構造物の信頼性評価をするうえで重 要なことを示している。

\section{2 環境要因および荷重履歴による劣化}

構造物が環境要因および荷重履歴により劣化する場合 の信頼性の評価例を Case(B) を対象に示す。劣化関数は (29) 式で評価でき, 環境要因による劣化は時間に対し線 形で, $t=60$ 年における残存強度は初期強度の $85 \%$ ある いは $70 \%$ と仮定する。2.1 節に述へたように環境要因に よる劣化の変動は考慮されていない。このときの劣化関 数の平均を図 6 に，対応する限界状態関数を図 7 に示す。 図 7 にはモンテカルロ法による評価結果も併せて示され ている。本論で示した近似解法による評価結果はモンテ カルロ法による評価結果と良く対応している。環境要因 および荷重履歷の両者を考慮した場合の $F(60)$ は荷重履 歴のみによる劣化を考慮した場合に比べ, $g_{a}(60)=0.85$ の場合は約 2.5 倍, $g_{a}(60)=0.70$ の場合は約 8 倍以上大 きく両者を同時に考慮することの重要性を示している。

\section{6 使用期間中の点検・メンテナンス計画}

使用期間中の定期的な点検およびその後の適切なメン テナンスは, 劣化した構造物を初期に近い状態に回復さ せることができる。しかし，点検及びメンテナンスは費 用を要するので, 点検の精度, メンテナンスの程度・頻 度，および必要とされる信頼性のレベルと，コストとの 間でのトレード・オフが存在する。最適な点検・メンテ ナンス計画を決定するためには，下記の最適化問題（一 般に非線形）を解く必要がある。

$$
\begin{aligned}
\text { Minimize } & C_{T} \\
\text { Subject to } & F(t)<P_{f}^{\prime}
\end{aligned}
$$

ここに, $C_{T}$ は点検とメンテナンスの全費用と構造物が 限界状態に入り込んだ場合の損失の期待值との和, $P_{f}^{\prime}$ は予め設定された目標限界状態確率である。設計段階 における最適化では 設計変数も (31) 式の決定変数とな り，初期建設費も $C_{T}$ に含まれる。疲労を対象とした鉒 構造物の最適な点検・メンテナンス計画を決定するため の研究は, 点検にて発見された損傷があるレベル以上に なった場合にはその部材を新しい製品（構造要素）と交 換し，部材耐力は初期の值に戻るという仮定の下になさ れている ${ }^{14)}$ 。しかし，点検の後に部材は交換されずに発 見された損傷だけがメンテナンスされる場合もある。こ の時, 部材の耐力は, 初期の状態には戻らないこともあ ろう。点検にて見落とされた損賃の影響，すなわち点検 の精度も最適な計画の決定に際して考慮に入れられる必 要がある。

本論文に述べられている信頼性解析手法は，最適な点 検・メンテナンス計画の決定に適用することができる。 既存の構造物への適用例を Case $(\mathrm{C})$ (荷重履歴による少 化のみを考虑）を対象にして示す。2つの計画案を考え る : (1) 点検とメンテナンスを龄 20 年及び 40 年に行いメ ンテナンスの後には部材耐力は初期の值に回復する（低 頻度・重整備），(2) 点検とメンテナンスを略 10,20,30, 40, 50 年に行うが部材耐力は初期の值の $95 \%$ までにし か回復しない(高頻度・軽整備)。劣化率はメンテナンス の前後で変わらないものとする。また, 点検・メンテナ ンスにかかる時間は無視する。これらの計画を用いた場 合の劣化関数を図 8 に, 対応する限界状態確率を図 9 に 示す。メンテナンスを行った時点で限界状態確率の傾き は減少し、これは, 部材耐力がより大きく回復した場合 ほど明確でありメンテナンスの効果がより大きいことを 示している。両計画案の信頼性に対する点検・メンテナ ンス効果は同等であり, もし $F(60) \leq 0.0025$ ならば両計 画案は合格である。この時, どちらの計画案を採用する かについては，(31) 式で示したように， $C_{T}$ を最小にす ることが一つの選択規準となろう。環境要因により劣化 


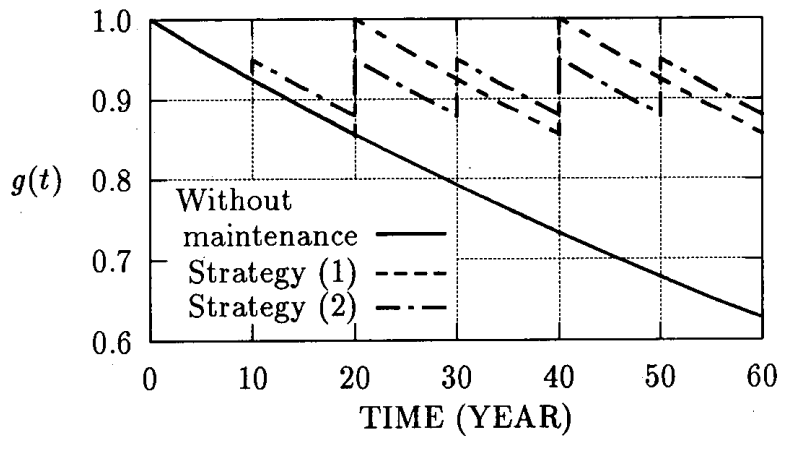

図 8: メンテナンスをした場合の部材の劣化関数

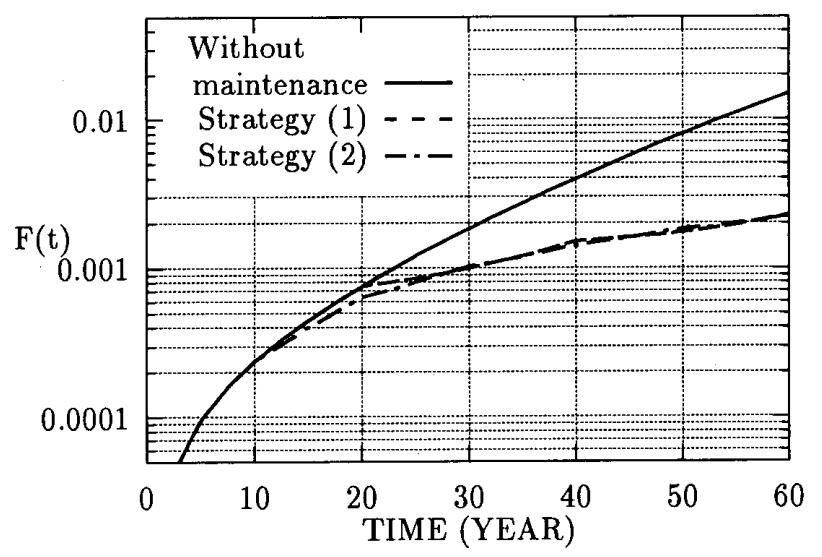

図 9:メンテナンスをした場合の部材の限界状態確率

する場合の点検及びメンデンンスの効果の不確定性を考 虑にいれた手法は既に考えられているが，非常に複雑で

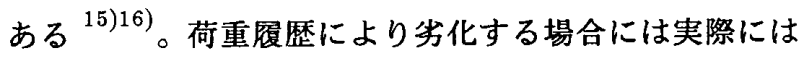
メンテナンス時期は予め決められたレベル以上または回 数の荷重の生起直後となろう。この場合荷重の生起時刻 はランダムなので，メンテナンス時期は最適化問題にお ける决定変数ではなくなり，確率変数となるので信頼性 解析は一層複雑なものとなる。

\section{7 あとがき}

本論は, 環境要因と荷重履歴の両者により耐力劣化す る場合の構造物の信頼性を評価するための新しい解析手 法について論じたものである。荷重履歴による耐力劣化 を環境要因による耐力劣化と同様に時間の関数として近 似評価することにより両者による耐力劣化を考虑に入れ た構造信頼性の評価が可能となり，また，それぞれの劣 化要因の構造信頼性に対する影響を同じ時間軸で比較す ることができる。荷重履歴により劣化する構造物の信頼 性は中央安全率, 荷重の平均生起率, 荷重効果の大きさ の変動係数に大きく影響され、これらの適切な評価は荷 重履歴により劣化する構造物の信頼性評価をするうえで
極めて重要である。

耐力劣化を考虑しながら構造物の信頼性を評価するこ とは，将来における総費用を最小とするうえで，既存の 構造物については点検・メンテナンスの時期, 頻度, お よび程度の決定, 設計段階ではさらに初期耐力を决定す るうえでの基礎となる。上記の手法をより現実的な構造 物に適用するためには, 耐力劣化やメンテナンスの効果 の定量的評価，およびメンテナンスに必要なコストや， 構造物が限界状態に入り込んだ場合の損失の算定に必要 なデータの蓄積をしていかなければならない。

\section{参考文献}

1) Washa, G. W., J. C. Seamann, and S. M. Cramer: Fiftyyear Properties of Concrete Made in 1937, ACI Materials Journal, Vol.86, No.4, pp.367-371, 1989

2) Koike, T. and H. Kameda: Reliability Theory of Structures with Strength Degradation in Load History, Memories of the Faculty of Engineering, Kyoto University, Japan, Vol.35, pp.331-360, 1973.10

3) Clifton, J. R. and L. I. Knab: Service Life of Concrete, National Bureau of Standards, NUREG/CR-5466, 1989

4) Hanai, M: Assessment of Load Factor by Means of Structural Reliability Theory, Trans. of A.I.J. No.231, pp.13$20,1975.5$

5）神田 順: 最適信頼性理論に基づく荷重係数決定の考察, 日本建筑学会大会学術講演梗概集, pp.23-24, 昭和 63 年 10 月

6) Mori, Y. and B. Ellingwood: Reliability-based Service-life Assessment of Aging Concrete Structures, J. Str. Engrg. ASCE, pp.1600-1621, 1993.5

7) Mori, Y. and B. Ellingwood: Time-dependent System Reliability Analysis by Adaptive Importance Sampling, Structural Safety, Vol.12, pp.59-73, 1993.4

8）洪起, 高梨晃一：信頼性理論に基つく最適設計，日本 建築学会構造系論文報告集, 第 418 号, pp.81-86, 1990 年 12 月

9）洪 起, 高梨晃一：繰り返し荷重を受ける構造物の信頼性 理論, 日本建築学会構造系論文報告集, 第 437 号, pp.1120,1992 年 7 月

10) Kameda, H. and T. Koike: Reliability Theory of Deteriorating Structures, J. Str. Div., ASCE, pp.295-309, 1975.1

11) Thoft-Christensen, P. and M. J. Baker: Structural Reliability Theory and Its Application, Springer-Verlag, New York, 1982

12) Melchers, R. E.: Structural Reliability; Analysis and Prediction, Ellis Horwood Ltd., West Sussex, England, 1987

13) Taylor, H. M. and S. Karlin: An Introduction to Stochastic Modeling, Academic Press, 1984

14) Thoft-Christensen, P. and J. D. Sorensen: Optimal Strategy for Inspection and Repair of Structural Systems, Civil Engrg. Systems., Vol.4, pp.94-100, 1987

15) Mori, Y. and B. Ellingwood: Maintaining Reliability of Concrete Structures I: Role of Inspection/repair, J. Str. Engrg. ASCE, pp. 824-845, 1994.3

16) Mori, Y. and B. Ellingwood: Maintaining Reliability of Concrete Structures II: Optimum Inspection/repair Strategies, J. Str. Engrg. ASCE, pp.846-862, 1994.3 (1994 年 5 月 10 日原稿受理, 1994 年 9 月 1 日採用決定) 